\title{
IMPLEMENTASI MODEL PEMBELAJARAN TAKE AND GIVE PADA RELASI DAN FUNGSI SMAN 1 BLANGKEJEREN
}

\author{
Hayatul Masiah ${ }^{1}$ \\ ${ }^{1}$ Sekolah Menengah Atas Negeri 1 Blangkejeren, Jl. Tgk.H.M Luddin KM.01, Bustanussalam Gayo Lues 24653, Indonesia \\ Email: hayatulmasiahgayo@gmail.com
}

\begin{abstract}
Abstrak
Rendahnya hasil belajar matematika serta aktifitas guru dan siswa merupakan suatu masalah yang mendasar di SMAN 1 Blangkejeren. Hal ini disebabkan proses belajar mengajar di kelas masih kurang diarahkan pada kegiatan-kegiatan yang mendorong siswa belajar aktif, dan kurangnya siswa terlibat langsung dalam proses pembelajaran. Penelitian ini bertujuan untuk meningkatkan hasil belajar siswa menggunakan model pembelajaran Take and Give pada materi reasi dan fungsi di SMAN 1 Blangkejeren. Penelitian ini menggunakan pendekatan kualitatif dengan jenis penelitian tindakan kelas, subjek penelitian adalah 31 siswa SMAN 1 Blangkejeren. Skor persentase yang diperoleh dari hasil tes akhir siklus I belum sesuai dengan kriteria hasil yang ditetapkan pada siklus yaitu hanya $45,16 \%$ yang mendapat nilai $\geq 65$, sedangkan hasil observasi terhadap kegiatan peneliti dan siswa diperoleh $77 \%$, hasil yang belum mencapai kriteria ini mengharuskan peneliti melanjutkan ke siklus II. Pada siklus II berdasarkan hasil tes telah mencapai 90,32\% dan hasil observasi terhadap kegiatan peneliti dan siswa juga sudah mencapai kriteria yang ditetapkan yaitu 93\%. Jadi berdasarkan hasil penelitian yang diperoleh dari analisis data menunjukkan bahwa pembelajaran dengan menggunakan model pembelajaran take and give dapat meningkatkan hasil belajar siswa.
\end{abstract}

Kata kunci: Model Pembelajaran Take and Give, Hasil belajar, Relasi dan Fungsi

\begin{abstract}
The low learning outcomes of mathematics and the activities of teachers and students is a fundamental problem at SMAN 1 Blangkejeren. This is due to the teaching and learning process in the classroom which is still less directed at activities that encourage active student learning, and the lack of students directly involved in the learning process. This study aims to improve student learning outcomes using the Take and Give learning model on material and function learning at SMAN 1 Blangkejeren. This study used a qualitative approach to the type of classroom action research, the research subjects were 31 students at SMAN 1 Blangkejeren. The percentage score obtained from the results of the end of the first cycle test is not in accordance with the criteria for the results set in the cycle that is only $45.16 \%$ who scored $\geq 65$, while the results of observations of the activities of researchers and students obtained $77 \%$, results that have not reached this criterion require researchers proceed to cycle II. In the second cycle based on the results of the test has reached $90.32 \%$ and the results of observations of the activities of researchers and students have also reached the established criteria of $93 \%$. So based on research results obtained from data analysis shows that learning by using take and give learning models can improve student learning outcomes.
\end{abstract}

Keywords: Take and Give Learning Models, Learning Outcomes, Relationships and Functions

\section{PENDAHULUAN}

Sekolah merupakan tempat setiap orang mengalami masa untuk bertumbuh dan berkembang. Setiap orang hampir separuh dari hidupnya menghabiskan waktu di sekolah dalam banyak kesempatan seperti kegiatan pembelajaran, ekstrakurikuler, dan berbagai aktivitas lainnya. Setiap orang yang pada masa sekolah harus melalui perjuangan berat di dalam kelas untuk memahami setiap materi selama proses belajar dan bersosialisasi dengan guru serta teman-teman dengan berbagai karakter berbeda di kelas. 
Matematika yang merupakan salah satu materi yang dipelajari di sekolah menjadi mata pelajaran wajib yang harus dikuasai sehingga menjadikan matematika dinilai cukup memegang peranan penting dalam membentuk siswa menjadi berkualitas. Matematika juga merupakan suatu sarana berpikir untuk mengkaji sesuatu secara logis dan sistematis. Oleh karena itu belajar matematika memiliki posisi penting dengan sifatnya yang sangat aplikatif dalam kehidupan seharihari. Pradima itu menjadikan matematika menjadi materi dasar yang wajib dipelajari pada tingkat bawah, menegah, maupun tingkat atas (Saputra, 2018). Mengingat pentingnya peranan matematika, sudah selayaknya pelajaran matematika perlu mendapat perhatian yang serius di berbagai jenjang pendidikan formal. Matematika yang selama ini sering dipandang sebagai salah mata pelajaran yang sulit dan sangat menakutkan harus bisa dihilangkan dan menjadi menyenangkan sehingga dapat meningkatkan hasil belajar siswa.

Hasil studi awal di lapangan dan berdasarkan pengalaman rekan sejawat penulis guru pelajaran matematika di SMAN 1 Blangkejeren diperoleh data bahwa penguasaan siswa terhadap pelajaran matematika masih tergolong rendah, termasuk salah satunya pada materi relasi dan fungsi, siswa masih kesulitan menganalisis aplikasi aljabar pada fungsi seperti fungsi invers dan komposisi fungsi. Kenyataan ini memberikan dasar peneliti mengambil kesimpulan sementara bahwa rendahnya pemahaman siswa mengakibatkan rendahnya hasil belajar matematika siswa yang disebabkan oleh berbagai faktor, diantaranya adalah penggunaan model pembelajaran yang monoton digunakan oleh guru dan media pembelajaran yang kurang maksimal. Selama studi awal yang peneliti lakukan pada SMAN 1 Blangkejeren menemukan bahwa pembelajaran matematika di sekolah tersebut masih menggunakan model pembelajaran konvensional yaitu suatu model pembelajaran yang banyak didominasi oleh guru seperti penugasan dan latihan tugas, aktivitas guru hanya sebagai penyampai materi sementara siswa duduk secara pasif menerima informasi pengetahuan dan keterampilan. Hal ini peneliti duga merupakan salah satu penyebab terhambatnya kreativitas dan kemandirian siswa sehingga menurunkan hasil belajar matematika siswa.

Di samping itu penggunaan media pembelajaran yang minim juga menjadi penyebab tersendiri yang menghambat kreatifitas siswa. Seharusnya ada pembaharuan media pembelajaran yang digunakan tidak hanya buku pelajaran saja. Saputra (2020) mengungkapkan penggunaan media menjadikan sumber belajar menjadi lebih beragam, pembelajaran yang sebelumnya cenderung hanya memanfaatkan media alat peraga dan buku ajar dapat lebih dimaksimalkan dengan bantuan media. Tabrani (1993) mengatakan Kehadiran media pada pembelajaran sangat membantu proses belajar mengajar sehingga transfer ilmu pengetahuan antara guru dan siswa menjadi lebih cepat dan efektif.

Berdasarkan permasalahan yang peneliti temukan, peneliti melakukan riset sederhana dengan merubah aktivitas mengajar yang lama dengan menerapkan model pembelajaran Take And Give dengan harapan dapat meningkatkan hasil belajar siswa dalam bidang studi matematika. Melalui model pembelajaran ini siswa dapat mengemukakan pemikirannya, saling bertukar pendapat, saling bekerja sama jika teman pasangannya mengalami kesulitan. Hal ini dapat meningkatkan motivasi siswa untuk mengkaji dan menguasai materi pelajaran matematika sehingga nantinya akan meningkatkan hasil belajar matematika siswa. Adapun salah satu kelebihan model pembelajaran take and give menurut Huda (2014) adalah Melatih siswa untuk bekerja sama dan menghargai kemampuan orang lain dan melatih siswa untuk berinteraksi secara baik dengan teman sekelas. Istarani (2011) menyatakan bahwa "Mengajar teman sebaya memberikan kesempatan kepada peserta didik untuk mempelajari sesuatu yang baik pada waktu yang sama saat ia menjadi narasumber bagi yang lain". Oleh karena itu, pemilihan model Take and Give dalam pembelajaran matematika pada penelitian ini diharapkan dapat meningkatkan hasil belajar siswa. 
Berdasarkan masalah yang peneliti utarakan sebelumnya, maka penelitian ini mengkaji "implementasi model pembelajaran take and give pada relasi dan fungsi SMAN 1 Blangkejeren.

\section{METODE PENELITIAN}

Pendekatan dalam penelitian ini menggunakan pendekatan penelitian kualitatif dengan Jenis penelitian yang dilakukan adalah penelitian tindakan kelas. Asrori (2008) mengemukakan "Penelitian Tindakan Kelas didefinisikan sebagai suatu bentuk penelitian yang bersifat reflektif dengan melakukan tindakan-tindakan tertentu untuk memperbaiki dan meningkatkan praktik pembelajaran di kelas secara lebih berkualitas sehingga siswa dapat memperoleh hasil belajar yang lebih baik". Tindakan yang diberikan adalah penggunaan model pembelajaran take and give pada pembelajaran matematika dengan melalui tahapan perencanaan, pelaksanaan tindakan, observasi dan refleksi.

Criteria ketuntasan yang digunakan pada penelitian ini adalah ketuntasan klasikal dengan standar minimal $85 \%$ siswa tuntas secara klasikal. Secara individual siswa akan tuntas belajar jika mendapat skor hasil belajar $\geq 65$.

\section{HASIL PENELITIAN DAN PEMBAHASAN}

\section{Paparan Data Tindakan Siklus I}

- Tes akhir tindakan Siklus I

Pelaksanaan tes akhir tindakan siklus I dilakukas setelah semua tahapan pelaksanaan dilakukan. Semua siswa hadir dan mengikuti tes akhir tindakan siklus I yang berjumlah 31 siswa. Pelaksanaan tes akhir dilakukan dengan memberikan 5 soal tes tulis uraian kepada siswa. Peneliti juga memberitahukan supaya mereka bekerja sendiri-sendiri, waktu yang disediakan 45 menit.

Berdasarkan nilai tes akhir siklus I diperoleh data bahwa, siswa yang mendapat skor $\geq 65$ sebanyak 14 siswa dan yang mendapat skor $<65$ adalah 17 orang siswa. Kemudian dilakukan perhitungan persentase keberhasilan pelaksanaan siklus I dengan hasil yang diperoleh hanya mencapai $45,16 \%$ siswa tuntas secara klasikal. Hasil ini belum sesuai dengan kriteria yang ditetapkan pada tindakan, jika $\geq 85 \%$ siswa belum mendapat skor $\geq 65$, maka pelaksanaan tindakan siklus I berdasarkan hasil tes belum berhasil dan harus dilanjutkan dengan pelaksanaan siklus II.

\section{- Hasil Observasi}

Observasi yang dilakukaan adalah dengan melibatkan teman sejawat untuk menilai proses pembelajaran sesuai dengan yang direncanakan. Berdasarkan hasil pengamatan observer selama kegiatan pembelajaran diperoleh kesimpulkan bahwa kegiatan belajar dengan menggunakan model pembelajaran Take and Give belum terlaksana dengan baik. Kekurangan pembelajaran yang telah dilakukan pada siklus I terlihat pada manajemen waktu yang digunakan pada saat pengerjaan lembar kerja siswa. Selama melakukan aktivitas siswa sangat menyita banyak waktu sehingga proses penyamaan persepsi setelah kegiatan tidak terlaksana dengan baik.

Hasil observasi diperoleh jumlah skor 37 pada pertemuan pertama dan diperoleh skor 40 dari skor ideal 50. Skor ideal diperoleh dari lembar observasi yang memuat 10 aktivitas guru dan siswa dengan masing-masing aktivitas diberi skor maksimal 5. Total skor diubah dalam bentuk persen dengan menggunakan rumus $\mathrm{SP}_{1}=\frac{37}{50} \times 100 \%=74 \%$ dan $\mathrm{SP}_{2}=\frac{40}{50} \times 100 \%=80 \%$. Kemudian 


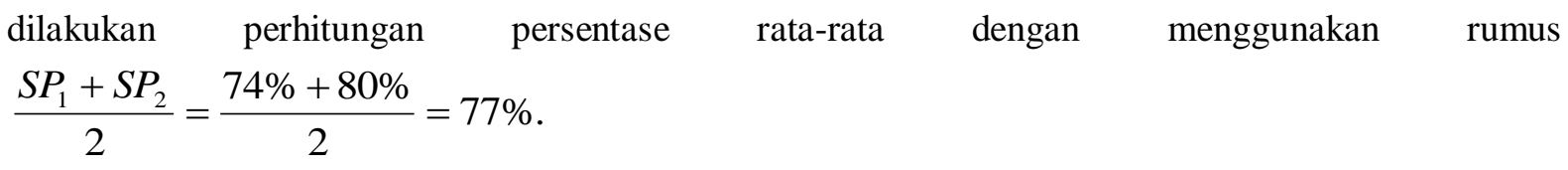

Berdasarkan keberhasilan proses pembelajaran terhadap kegiatan peneliti pada siklus I menunjukkan bahwa $77 \%$ pembelajaran dilaksanakan dengan baik. Dengan demikian, kegiatan peneliti dalam proses pembelajaran pada siklus I sudah berlangsung sesuai dengan yang diharapkan namun dengan perbaikan pada saat penggunaan waktu pada aktivitas siswa.

\section{- Refleksi}

Untuk mengetahui apakah siklus I sudah berhasil atau belum, maka perlu dilakukan refleksi. Berdasarkan hasil tes akhir tindakan siklus I diperoleh data bahwa $45,16 \%$ siswa mendapat skor $\geq 65$ atau tuntas secara klasikal. Dengan demikian kriteria keberhasilan hasil pembelajaran belum mencapai kriteria yang telah di tetapkan pada tindakan yaitu $\geq 85 \%$ siswa tuntas secara klasikal. Pada saat pelaksanaan tindakan peneliti kesulitan menghadapi beberapa siswa yang membuat keributan sehingga hilangnya konsentrasi peneliti dalam mengkondisikan kelas dengan baik, sehingga berdampak pada kegiatan peneliti yang dilakukan kurang efektif untuk setiap fase pembelajaran. Aktivitas siswa dalam mengerjakan LKS sedikit terganggu dengan aktivitas diluar pembelajaran. Kegiatan siswa masih harus menunggu instruksi dari guru sehingga banyak waktu tidak termanfaatkan secara maksimal. Namun demikian hasil observasi secara keseluruhan menunjukkan bahwa kegiatan penelitian dalam mengajar dan kegiatan siswa dalam belajar sudah baik sesuai dengan yang direncanakan, hal ini terbukti dengan presentase hasil observasi terhadap kegiatan peneliti mencapai $77 \%$.

\section{Paparan Data Tindakan Siklus II}

\section{- Tes akhir tindakan Siklus II}

Tes akhir tindakan siklus II diikuti oleh 31 siswa. Tes akhir tindakan dilakukan setelah tahapan siklus II selesai dilaksakan. Pada tes ini diberikan 5 soal essay yang dikerjakan siswa pada lembar yang telah disediakan. Sebelum mengikuti tes terlebih dahulu tempat duduk siswa dijarangkan untuk menjaga kemungkinan siswa bekerja sama dengan temannya. Di samping itu, peneliti juga memberitahukan kepada siswa untuk bekerja secara individu, waktu pelaksanaan tes dialokasikan selama 45 menit. Kriteria yang digunakan pada tes akhir siklus II masih sama dengan yang dilakukan pada siklus I.

Berdasarkan hasil tes akhir siklus II diperoleh data bahwa, siswa yang mendapat skor $\geq 65$ sebanyak 28 orang siswa dan siswa yang mendapat skor $<65$ sebanyak 3 orang siswa. Setelah dihitung persentase maka keberhasilan tes akhir tindakan berdasarkan nilai siswa tersebut mencapai $90,32 \%$, dengan demikian sesuai dengan kriteria yang ditetapkan pada tindakan, jika $\geq 85 \%$ siswa mendapat skor $\geq 65$, maka pelaksanaan tindakan siklus II sudah berhasil dan tidak perlu dilanjutkan ke siklus berikutnya.

\section{- Hasil Observasi}

Dari hasil pengamatan peneliti selama kegiatan pembelajaran pada siklus II, dapat dinyatakan bahwa kegiatan pembelajaran dengan model pembelajaran Take and Give sudah terlaksana dengan sangat baik. Hasil pengamatan dilakukan terhadap kegiatan guru dan siswa dalam proses belajar dengan mengisi lembar observasi yang telah disediakan oleh peneliti. 
Dari hasil observasi pengamat diperoleh skor 45 pada pertemuan pertama dan diperoleh skor 46 pada pertemuan kedua dengan skor maksimal 50. Dengan menggunakan rumus $\mathrm{SP}_{1}=\frac{45}{50} \times 100 \%=90 \%$ dan $\mathrm{SP}_{2}=\frac{48}{50} \times 100 \%=96 \%$. Kemudian dilakukan perhitungan rata-rata dengan rumus $\frac{S P_{1}+S P_{2}}{2}=\frac{90 \%+96 \%}{2}=93 \%$.

Dengan melihat taraf keberhasilan kegiatan siswa terhadap pembelajaran pada siklus II, menunjukkan bahwa pembelajaran termasuk kategori sangat baik. Dengan demikian dapat disimpulkan bahwa kegiatan siswa dalam kegiatan pembelajaran juga sudah sesuai dengan yang direncanakan.

\section{- Refleksi}

Setelah mengetahui hasil siklus II dan melewati seluruh tahapan perlu dilakukan refleksi untuk melihat kekurangan yang terjadi selama pelaksanaan tindakan. Berdasarkan hasil tes akhir tindakan siklus I diperoleh data bahwa $90,32 \%$ siswa mendapat skor $\geq 65$. Dengan demikian kriteria keberhasilan hasil pembelajaran sudah mencapai kriteria yang telah di tetapkan pada tindakan. Ketika pelaksanaan tindakan peneliti sudah bisa mengendalikan kelas dengan baik walaupun masih ada sebagian kecil siswa yang membuat keributan dan tidak fokus dengan pembelajaran. Sebagian siswa sudah membuat catatan-catatan kecil untuk memudahkan belajar dan pada tahap evaluasi sudah aktif, memperhatikan presentasi teman. Hasil observasi juga menunjukkan peningkatan aktivitas siswa dengan diperoleh hasil $93 \%$ presentase efektivitas tindakan selama penelitian.

\section{Hasil wawancara}

Setelah selesai tes akhir siklus II maka dilakukan wawancara. Dari hasil wawancara peneliti dapat disimpulkan bahwa semua subjek menyukai belajar matematika dengan menggunakan model pembelajaran Take and Give, karena siswa lebih mudah memahami materi. Dan juga semua subjek setuju jika model pembelajaran Take and Give diterapkan pada materi lainnya.

Jadi dapat disimpulkan bahwa dari hasil penelitian penerapan model pembelajaran Take and Give pada materi relasi dan fungsi SMAN 1 Blangkejeren telah terlihat adanya peningkatan hasil belajar siswa dari siklus I hingga siklus II dan juga dari hasil observasi aktivitas siswa mengalami peningkatan yang baik.

\section{KESIMPULAN}

a. Penerapan model pembelajaran Take and Give dapat meningkatkan hasil belajar siswa pada materi relasi dan fungsi SMAN 1 Blangkejeren. Hasil tes akhir tindakan siklus I terlihat bahwa siswa yang memperoleh skor $\geq 65$ mencapai $45,16 \%$ dan pada siklus II terlihat bahwa siswa yang memperoleh skor $\geq 65$ mencapai $90,32 \%$.

b. Kegiatan peneliti dan siswa dalam pelaksanaan proses pembelajaran dengan menggunakan model pembelajaran Take and Give pada tiap siklus mengalami peningkatan, hal ini terlihat dari analisis kegiatan guru dan dari siklus I dan siklus II yaitu $77 \%$ menjadi $93 \%$. 


\section{REFERENCES}

Asrori, Muhammad. (2008). Penelitian Tindakan Kelas. Bandung: CV Wacana Prima.

Huda, Miftahul. (2014). Model-Model Pengajaran dan Pembelajaran. Yogyakarta: Pustaka Pelajar.

Istarani. (2011). 58 Model Pembelajaran Inovatif. Medan: Media Persada. Yogyakarta: Pustaka Belajar.

Saputra, E. (2018). Melihat Motivasi Belajar Matematika Siswa Dari Kompetensi Guru Selama Pembelajaran. Jurnal As-Salam, 2(2), 60-67. https://doi.org/10.37249/as-salam.v2i2.34

Saputra, E,. Ulya, K,. Wahyuni, S,. Rahmadhani, E,. Hakim, H. (2020). Media application in anchored instruction to support mathematics teachers' pedagogical content knowledge. Journal of Physics: Conference Series, $1460 \quad$ (2020) 012042. https://doi.org/10.1088/1742$6596 / 1460 / 1 / 012042$

Tabrani, R \& Yani, D. (1993). Penuntun Belajar yang Sukses. Jakarta: Nine Karya. 